\title{
THE TREATMENT OF ANURIA
}

\author{
By Gabriel Richet, Jean Crosnier and Georges Mathé
}

Service du Professeur Agrégé Yean Hamburger, Hôpital Necker, Paris

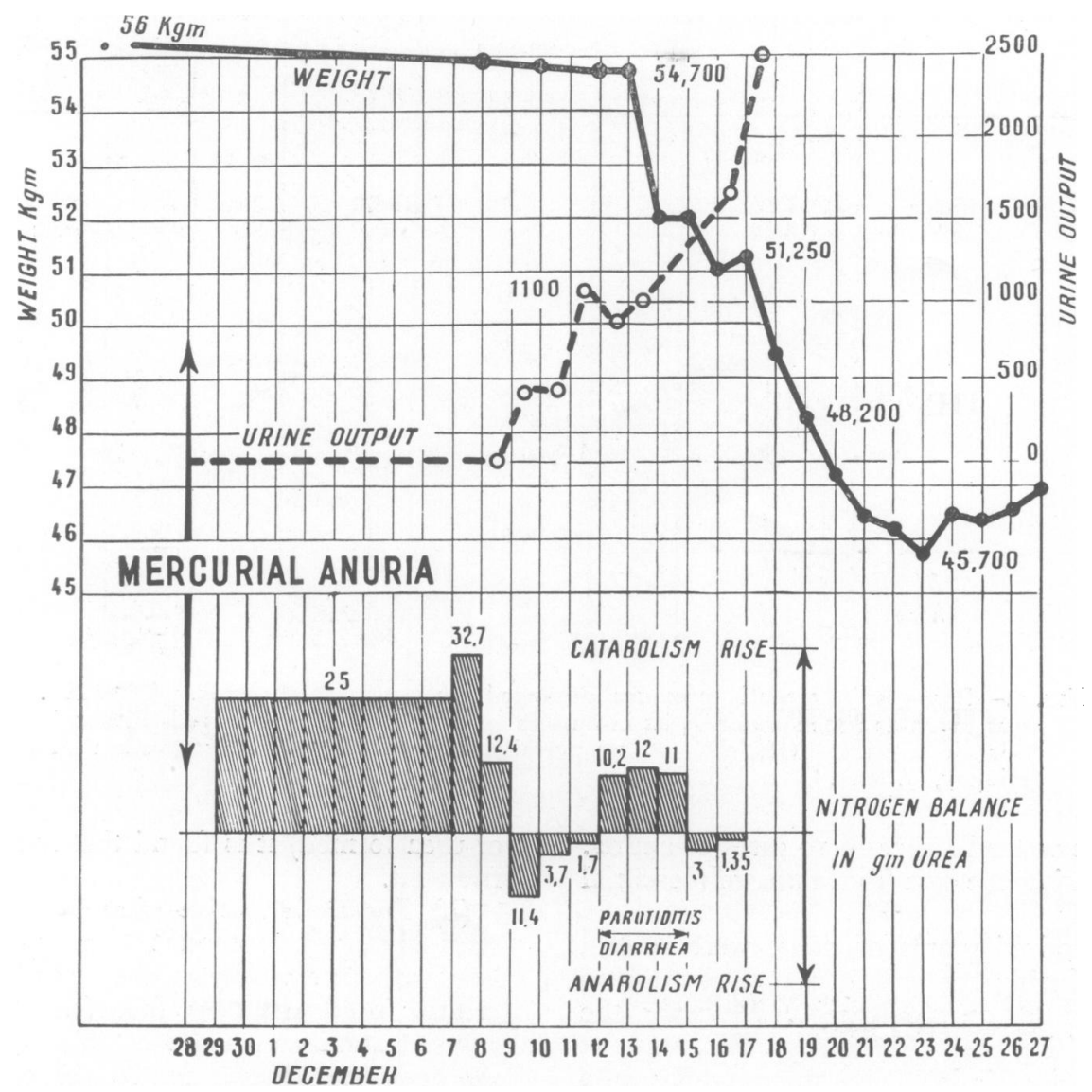

FIG. I.-Weight curve, daily urine output and nitrogen balance in a case of mercurial anuria. (Reproduced by permission from the 'Ciba Symposium of the Kidney,' J. \& A. Churchill, Ltd., and Soc. Med. Hop. Paris, Masson).

We shall confine ourselves in this article to the symptomatic treatment indicated in all cases of acute renal insufficiency, without discussing that of the underlying cause in each particular type.

\section{Basic Physio-Pathological Principles}

The following are taken from the literature and from personal observations of 76 patients treated for anuria and of 29 dogs and 95 rats after bilateral ureteric ligation.
(1) The disorder of hydration and of osmotic equilibrium.

This is one of the most important disturbances.

(a) Total body water. When an anuric subject receives a fluid intake equal to the insensible loss, a rise of the proportion of water in the organism takes place. This phenomenon has been clearly demonstrated by the progressive increase of the heavy water space in our dogs (Hamburger and Mathé, 1954) and by desiccation in the rats. It has been 


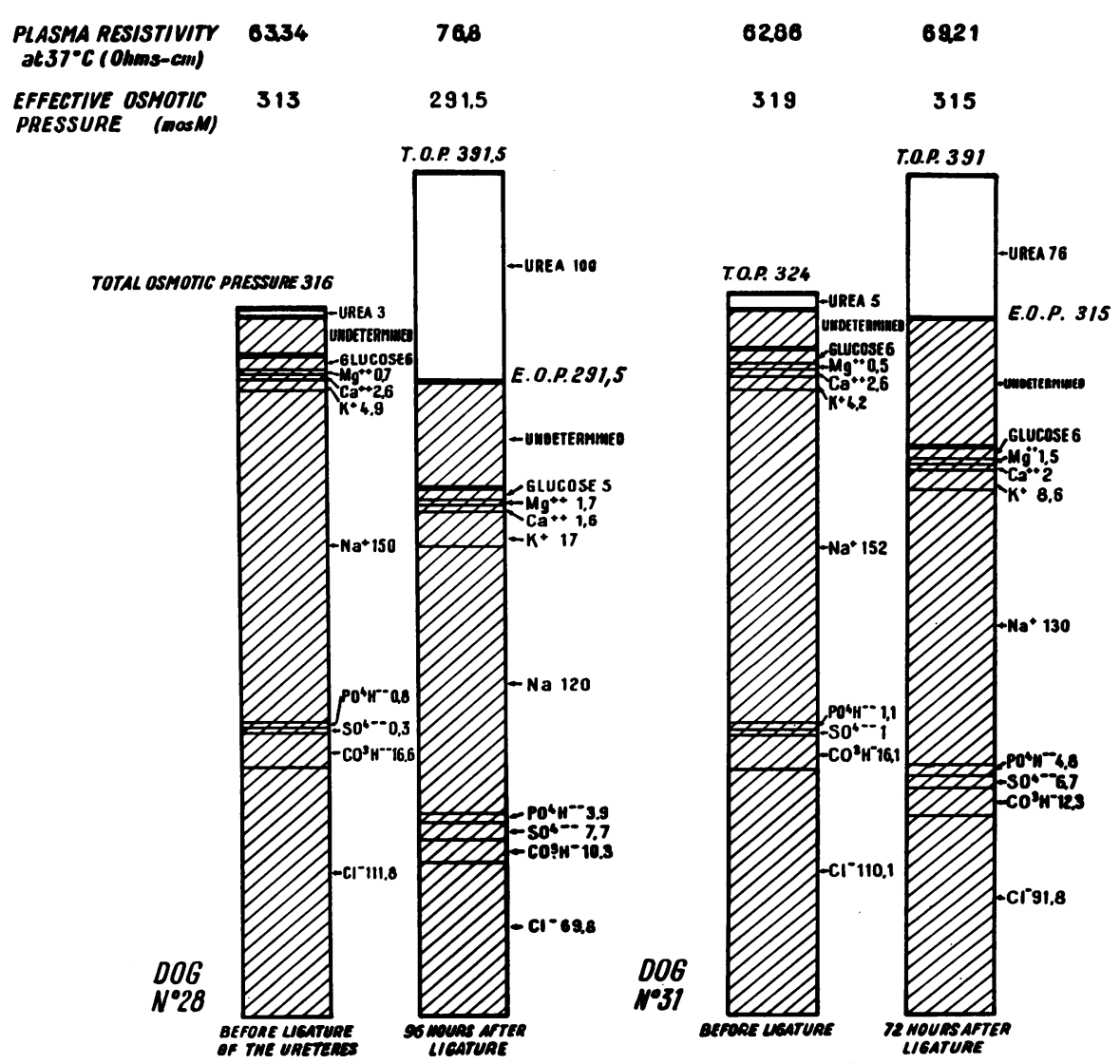

Fig. 2.-Changes in osmotic pressure produced by renal insufficiency. Dog. No. 28 was given as much water as its insensible loss. Dog. No. $3 \mathrm{I}$ received neither water nor electrolytes. (Reproduced by permission from the "Ciba Symposium on the Kidney,' J. \& A. Churchill, Ltd.).

shown by the water balance in 10 cases of anuria. Fig. I summarises the data from a case of mercurial anuria.

Several hundred grams of tissue were broken down daily during the anuric period, producing $25 \mathrm{gm}$. urea a day on the average. However, the weight stayed between 54.7 and $55 \mathrm{Kg}$., until at the onset of diuresis it fell by about $12 \mathrm{Kg}$. in a few days, although the nitrogen balance became positive again.

This was found in ro patients (Hamburger and Richet, 1952). The weight was almost constant during anuria, although catabolism was considerable, indicating marked tissue destruction. During the diuretic phase the fall of weight averaged $9.5 \mathrm{~kg}$. (when catabolism was normal again and during a phase of tissue repair). This cannot be due to wasting; it must be due to the loss in the urine of excess water accumulated during anuria. In man or animals, if a calculation is made of the water formed from carbohydrate (from the ingested glucose) and from protein (from the amount of urea formed) it is found that most of it comes $\stackrel{\circ}{\Phi}$ from fat.

(b) The redistribution of water. In an animal $\stackrel{3}{3}$ receiving the same amount of water as its insensible $\bar{P}$ loss, without electrolytes, the volume of the extracellular fluid generally falls (shown by haemoconcentration and a fall of thiocyanate space in $\underline{3}$. the dogs (Hamburger and Mathé, 1954) and by a 5 fall in plasma volume (Muirhead et al., $1952 ;$ Harris et al., 1952) ). Given therefore the rise of $\delta$ total body water and a tendency to extracellular

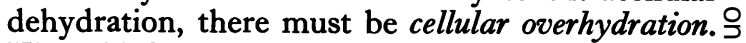
The chief reason for this shift in water is an extracellular hypotonicity (Fig. 2), mainly due to electrolyte losses from the gut. Certain cellular N disturbances not well understood also contribute (Hamburger and Mathé, 195I, 1952).

In man, the phenomenon is more complex $\mathrm{N}_{\mathrm{\omega}}$ When the patient arrives in hospital he generally shows the clinical symptoms of extracellulare dehydration associated with those of cellular over- $\mathbb{\Phi}$ hydration. The former is shown by wrinkled, ? 
inelastic skin, rings under the eyes, low blood pressure and haemoconcentration, the last two indicating involvement of the intravascular compartment. This hypovolaemia is dangerous and calls for urgent correction. Cellular overhydration is shown by anorexia, nausea, vomiting, cramps, lassitude, electroencephalographic changes and even coma. There are two valuable signs of cellular overhydration : increase of mean corpuscular volume and fall of effective plasma osmotic pressure (Hamburger et al., I950a). The latter may be derived $(\mathrm{I})$ by the estimation of the freezing point (subtracting that fraction due to the urea), (2) by measuring the electrical conductivity, or (3) by the sum of the concentrations of the various electrolytes expressed in milli-osmols.

When the subject is brought to hospital after some days' anuria and has been previously treated (particularly by standard procedures for ' rehydration'), we often find overhydration of both intracellular and extracellular compartments. The first is shown by a tendency to oedema, hypertension and haemodilution, the second by the symptoms described above.

\section{(2) Disturbance in the electrolytes and acid-base balance.}

Cations. The plasma sodium is generally low, as is the calcium ; potassium and magnesium are high. The abnormal potassium and calcium levels may produce changes in the E.C.G.

Anions. Low chloride and bicarbonate and high sulphate and phosphate are found. There is generally a fixed acidosis with low alkali reserve and $\mathrm{pH}$. On comparing the cations with the anions, a considerable deficit of the latter appears, partly made up by organic acids.

\section{(3) Nitrogen retention and increased catabolism.}

The rise of blood urea does not appear responsible for any symptoms. Other nitrogenous products are found in excess in the plasma: uric acid, creatine, creatinine, ammonia, amino-acids and polypeptides. We found that the residual nitrogen, an overall term for these, given by the difference between the total non-protein nitrogen and the urea nitrogen, rises relatively less in renal insufficiency than the urea itself. The blood urea level should not be considered an indication of the degree of renal failure, for it reflects two other factors : the nitrogen intake and protein catabolism. The diet in acute renal insufficiency must be protein-free but even then the quantity of urea formed is considerable. As in many other severe pathological conditions, increased destruction of the tissue proteins occurs for a number of reasons :- (a) In man, starvation itself leads to the daily destruction of $30-60 \mathrm{gm}$. This has been shown in the experimental animal (Table I). Sufficient glucose and fat must therefore be given

\section{TABLE I}

Comparison of Blood Urea Levels in a Group of AnURic Rats on Complete Starvation and a Group Receiving Sufficient Glucose fOR ENERgy REQUIREMENTS (CASTAIGNE, I 949 ).

Urea at $45^{\text {th hour, }}$ $m g . /$ ror $m l$.

Mean of rats of complete starvation

Mean of rats receiving $200 \mathrm{cal} / \mathrm{Kg}$. body weight in 24 hours .. $\quad \cdots \quad 256 \pm 45$

Comparison of Blood Urea Levels in AnUric Rats Treated with Glucose Diet and with Standard Diet With Proteins (HAMburger et al., I 95I)

Urea at 46 th hour, $\mathrm{mg} . / 100 \mathrm{ml}$.

Controls (Ic rats) 0.030

Anuric rats:

$\begin{array}{llll}\text { Glucose diet (ro rats) } \quad \ldots & \ldots & 0.295\end{array}$

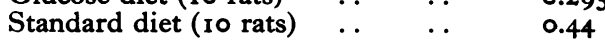

Comparison of Blood Urea Levels in a Group of AnURic Rats on Complete Starvation and a Group Receiving a Glucose Diet Sufficient for ENERgY ReQUiREMENTS (CASTAIGNE, I 949).

Urea at $45^{\text {th }}$ hour, mg./ $100 \mathrm{ml}$.

Mean of rats on complete starvation

Mean of rats receiving $200 \mathrm{cal} . / \mathrm{Kg}$. $0.331 \quad 0.048$ body weight in 24 hours .. $\quad \ldots .0 .256 \quad 0.045$

to provide calories for basal requirements. (b) Intoxication and infection. Protein metabolism in anuric patients is increased initially, and when there is infection. (c) Hypotonicity and cellular overhydration. We have shown in the $\mathrm{dog}$ and rat that in osmotic hypotonicity protein metabolism is greater than in isotonicity or hypertonicity (Fig. 3). Hypotonic dogs with extracellular dehydration as well as overhydrated rats show this phenomenon: it seems logical to consider the cellular overhydration common to both as responsible for the increased nitrogen catabolism.

(4) Effects of these disturbances on the kidney.

Essentially caused by renal insufficiency, these disturbances can themselves impair renal function, at any rate the disturbance of hydration can. Just as cellular dehydration can by itself cause or maintain anuria by lowering GFR, it seems that cellular overhydration may equally well maintain and perhaps cause anuria. This is suggested by the finding, often made in the course of correction of osmotic hypotonicity, that at the same time as the clinical signs of the syndrome described above disappear the onset of diuresis occurs. The experimental results of Funck-Brentano (1953-4), who has been able to provoke anuria in rabbits by overhydration with hypotonic fluid, strongly favour this hypothesis.

\section{(5) Blood disorders.}

A considerable polymorph leucocytosis and anaemia are usual. In the marrow an intense granulopoiesis is seen. The anaemia appears to 


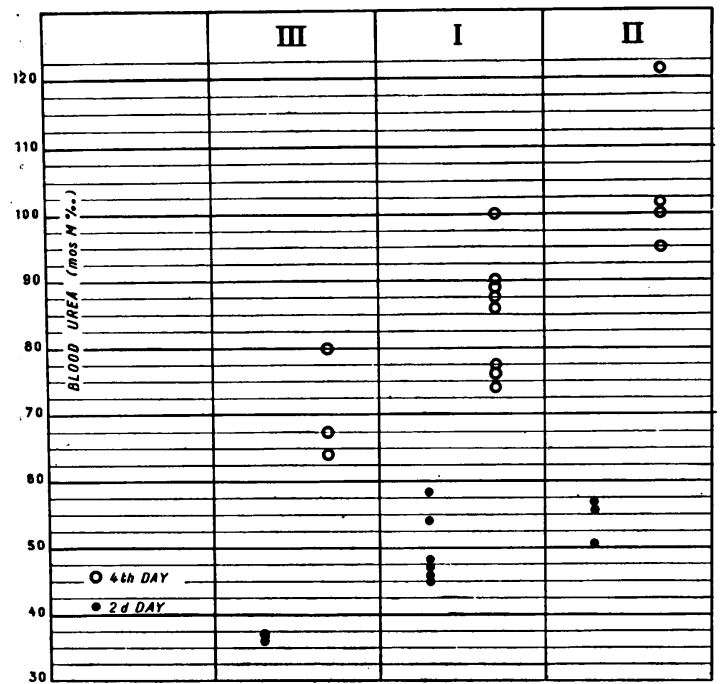

Fig. 3.-Blood urea on the and and 4 th days after ureteric ligation in dogs. Group I: given neither water nor electrolytes. Group II : insensible loss replaced. Group III: given a hypertonic solution of sodium chloride and sodium bicarbonate daily. (Reproduced by permission from the ' Ciba Symposium on the Kidney,' J. \& A. Churchill, Ltd.)

result from increased haemolysis (Muirhead et al., 1952), particularly at the onset, and later from acute depression of erythropoiesis in the marrow (Richet et al., 1954) (Fig. 4).

(6) Onset of diuresis.

After the return of diuresis, renal function remains very abnormal for many more weeks (Bull et al., 1950). It is therefore still necessary to control blood levels and to correct any disturbances resulting from impaired renal function.

\section{Conservative Treatment}

During anuria there is no way of hastening the onset of diuresis, and treatment must be directed towards allowing the organism to survive this period. The concepts which have been outlined dictate its course. The following must be prevented : disturbances of water and osmotic balance, disturbances of electrolytes and acid-base balance, increased nitrogen catabolism, and infection. Essentially it comprises exact diet, correction of abnormalities of body water or electrolytes, and prevention or treatment of complications such as anaemia, blood loss and urinary infection.

(I) The Diet.

The aim is to give $1600-2000$ calories covering the basic requirements in the form of carbohydrate and fat. (a) The regime of Borst (1948) consists of $300 \mathrm{gm}$. sugar and $150 \mathrm{gm}$. of butter,

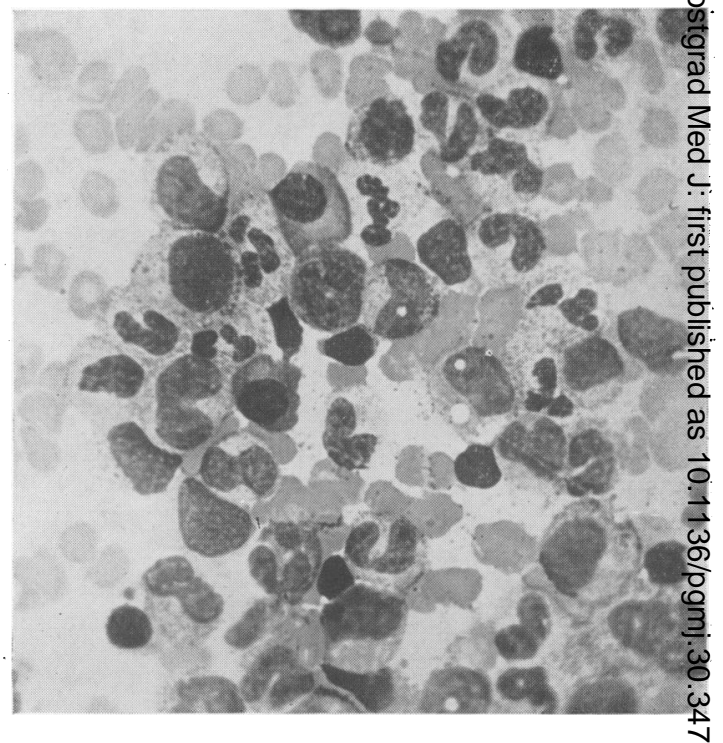

Fig. 4.- Sternal marrow in acute renal insufficien showing extreme depression of erythropoiesis with intense granulopoiesis.

mixed and divided into pats which are iced, 2-3 oranges. Actually this includes too much qa $_{\text {. }}$. (b) The regime of Hamburger (Hamburger et 195I). This provides 1800 calories with on $\frac{T}{5}$ gm. protein, and comprises $50 \mathrm{gm}$. low prosem bread, $60 \mathrm{gm}$. butter, I $00 \mathrm{gm}$. honey; sala apples or pears $200 \mathrm{gm}$., $100 \mathrm{gm}$. sweets, I $50 \mathrm{gm}$ sugar, an allowance of vitamins. The drawbace of this lies in the not insignificant potassium content. (c) Deproteinized milk. In France reconstituted milk is available, low in nitrogen and rich in calories and flavoured with fruit juice of coffee, one litre providing about 2,250 calorie? (d) Feeding by gastric tube (Bull et al., 1949) allows all the glucose and fat to be given. 400-45 gm. glucose can be dissolved in the daily fluid ration, to which may or may not be added 50-100 gm. oil. Actually, a duodenal tube must be used as the gastric one does not prevent vomitin Moreover, giving such large quantities of glucos in very concentrated solution tends to provole diarrhoea which may be difficult to contro\$, (e) Intravenous feeding. It is possible to provide sufficient calories by daily administration of $\bar{q}$ litre of 30 per cent. glucose solution given by slow intravenous drip with $30-60$ units of insulin? Unfortunately this soon causes venous thrombosity even if heparin is added to the bottle. Moreover it is often impossible to reconcile this with the limited fluid requirements of these patients.

Practical application. There is no universal way of dealing with these patients : each case must.be 
TABLE 2

Clinical Control.

Weight: Normally the anuric subject should lose $100-300 \mathrm{gm}$. daily (loss corresponding to

Respiration: the extrarenal elimination of endogenous formed water)

Temperature:

Alimentary losses:

indicating the daily fluid loss

The appearance of the patient: oedema, dryness of the tongue, etc.

C.N.S. and digestive disturbances

Pulse and blood pressure

Indicating changes in total body water

Indicating changes in partition of water

TABLE 3

Biochemical Control
Daily Estimation of:
Freezing point of plasma Blood urea
Resistivity of plasma
Specific gravity of plasma
Haematocrit
Blood levels of $\mathrm{Cl}, \mathrm{Na}, \mathrm{K}$.
Every other day:
Blood count
Alkali reserve and $\mathrm{pH}$ of blood
Once a week:
Estimation of all the ions
Giving effective Osmotic Pressure of plasma

$$
\text { Indicating hydration of the vascular }
$$

ance will vary between none at all and I.5-2.0 litres. (b) Electrolytes. (i) Sodium salts must be regarded in two ways : (a) the amount to be given. Sodium salts are principally responsible for the osmotic pressure of ECF and therefore for the internal partition of water. A variable quantiy must be given daily to maintain normal osmotic pressure. When there is overhydration, not only must fluid be prohibited but salt also. On the other hand, dehydration can only be corrected if enough sodium is given to reconstitute the ECF volume : the quantities of salt and water to be given will then depend on the disturbances observed. They must be given in the proportions of normal saline when the main one is extracellular. An increasing amount of water must be given according to the estimate of the intracellular loss. The oral route can be used (water and salt capsules) or the subcutaneous or intravenous drip (normal saline). Intravenous hypertonic saline may have to be combined with a dry diet, when an increase of total body water occurs with diminished effective osmotic pressure of the plasma. The need for sodium salts may vary, therefore, between none and $10 \mathrm{gm}$. or even more in 24 hours. (b) The sodium salt to be given. Sodium chloride, particularly as intravenous hypertonic saline, should be used when there is no disturbance of acid-base balance. Actually the anuric subject is usually acidotic; sodium bicarbonate should therefore be given either with sodium chloride or by itself, by mouth or as an isotonic solution intravenously (Fig. 5).

(ii) Potassium salts and correction of the blood level of potassium. A watch is kept on the blood level chemically and by repeated electrocardio- 


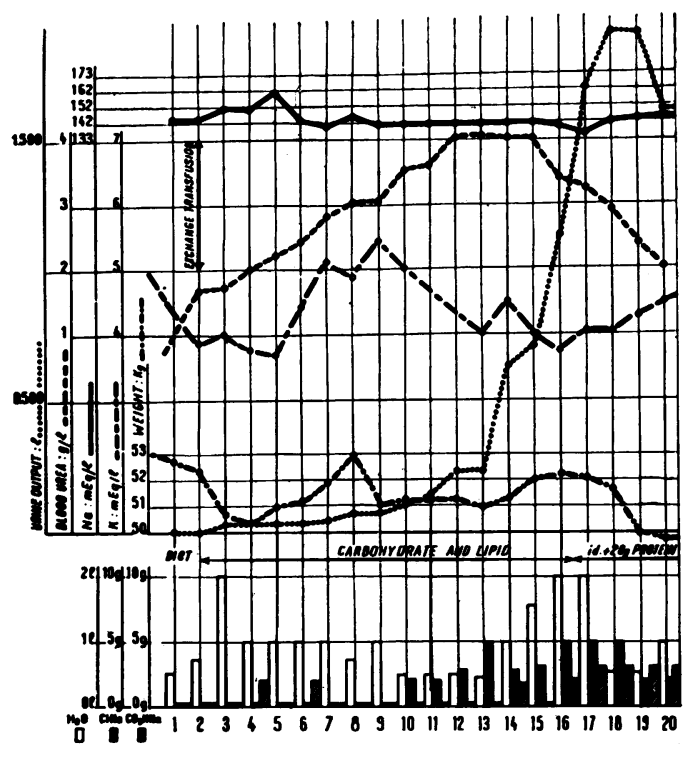

Fig. 5.-Transfusion anuria, treated by the glucose-fat diet without extra-renal correction. Note the different quantities of water, salt and bicarbonate given daily according to the clinical state and the blood chemistry.

grams. The blood potassium level, normal in the first week of anuria, then begins to rise progressively, often rapidly reaching dangerous levels. As far as possible hyperkalaemia must be prevented by withholding food rich in potassium (particularly oranges, lemons and bananas, which the patient's relatives, with all good intentions, press upon him), and also by a high calorie intake reducing protein catabolism to a minimum. If in spite of this the blood potassium level continues to rise the risk of a fatal outcome calls for active treatment. The use of hypertonic glucose and small doses of insulin by the intravenous route does not seem to us to be particularly effective. More beneficial will be the use of cation exchange resins. Their use in anuric subjects must be cautious, because of the danger of acidosis (Harvey et al., 1953). Evans et al. (1953), however, reduced this risk by using sulphonic resins charged with sodium. The most effective method at our disposal and the only one capable of removing large quantities of potassium without any danger is extrarenal dialysis ; intestinal perfusion in particular has given excellent results in our hands.

On the other hand, in certain cases (with severe diarrhoea and vomiting), hypokalaemia may arise, which should be corrected by ordering fruits rich in potassium, by the administration of potassium salts (the chloride if there is alkalosis, bicarbonate or citrate if there is acidosis), in a dose of
I-I 0 gm. every 24 hours orally, or, in certain caseg, intravenously.

(3) Prevention or treatment of certain complication?

The commoner complications in the course off anuria must be dealt with in the most practicab?e way. (a) Anaemia and the haemorrhagic syndromie. The constant, progressive anaemia of prolongäd anuria may be associated with a haemorrhagic syndrome, which is serious when bleeding as widespread or recurrent. The cause is unknowh, and there is no effective treatment. Prophylagtically we usually prescribe throughout anuria Vitamin $\mathrm{K}$ and daily, or every other day, give ${ }_{-}^{\infty}$ small transfusion of $150-200 \mathrm{ml}$. of fresh blood of the same group. Obviously this must be con sidered in computing the daily fluid balance. (b) Digestive disturbances. Severe vomiting oft necessitates feeding by tube or by vein. Moze important, however, is the fact that alimenta losses, either vomiting or diarrhoea, cause coin siderable loss of water and electrolytes (chloride, sodium and potassium) ; important because it often the cause of delayed collapse. As far as practicable, a precise estimate must be made, for exact replacement. In some cases the cause can be found and treated, such as a disturbanc of osmotic equilibrium, abuse of hypertonic gluç্⿸丆口马. or toxic effects of antibiotics. (c) Controf if infection. Antibiotics must be used in eyeng anuria whatever the cause, particularly to pregent urinary infection. Moderate doses are given for anuria makes it possible to attain very high bof levels. Much larger doses can be given if a sept tic focus is suspected. Nevertheless a certain dangerr must be foreseen in the anuric subject; with streptomycin, at moderate blood levels we hape seen a number of cochlear complications.

Conservative treatment, of which we ha $\overrightarrow{g e}$ outlined the main principles, may be sufficient to enable us to avoid recourse to extrarenal corre $\bar{E}$ tion, but it is essential to keep control of the situation right up to complete recovery. In particular, the diuretic phase is a critical period of anuria, when the same clinical and biochemical control must be maintained and the same cage taken in giving drugs and salt and water. TRe danger at this time is of being too timid ; there is true water and salt diuresis, and often a considerable loss of potassium, and if these are nit replaced collapse may occur.

\section{Extrarenal Correction}

N

If careful conservative treatment is powerles to prevent serious deterioration, extrarenal cor ${ }^{2}$ rection is justified. This is indicated when three conditions are fulfilled : (i) retention of a suepstance whose plasma level is reaching alarmi figures, for example, blood urea above $400 \mathrm{mg} / \mathrm{r}$ 
ml. or hyperkalaemia above 7.5 m.equiv./1 ; (ii) absence of any signs foreshadowing the imminent onset of diuresis ; (iii) when the renal failure is considered reversible. The exact indications vary according to the procedure used-exsanguinotransfusion, artificial kidney, peritoneal dialysis or intestinal perfusion.

\section{(I) Exsanguino-transfusion}

The principle consists in replacing part of the blood volume by a large transfusion at the same time as exsanguination. Since the blood withdrawn must include some of that infused, the volume exchanged must be less than that of the latter.

a transfusion

equal to

$$
50 \% \quad 100 \% \quad 150 \% \quad 200 \% \quad 300 \%
$$

$\begin{array}{llllll}\text { actually replaces } & 39 \% & 63 \% & 78 \% & 87 \% & 95 \%\end{array}$
of the blood volume.

Technique (Dausset, 1950). From each donor of the same blood group as the patient, $500 \mathrm{ml}$. of blood are withdrawn into a sterile flask with $15 \mathrm{ml}$. of ro per cent. sodium citrate. A transfusion is given into an antecubital vein, while at the same time blood is withdrawn by a plastic catheter inserted cranially into the saphenous vein in the femoral triangle. One end of this catheter lies in the inferior vena cava, the other drips into a flask connected to a suction pump. The transfusion and exsanguination are regulated so that the volume of the former is always $200-300 \mathrm{ml}$. greater than the amount removed, and never more. To exchange 5 litres should take 90-120 minutes.

Complications. The sodium citrate increases the amount of sodium in the ECF but this is only dangerous when the subject is already overloaded. It may also provoke tetany by producing alkalosis. A discrepancy between the amount of blood given and that withdrawn may produce severe collapse-it is important to make sure that the amount given is always slightly greater. On the other hand, too rapid infusion may provoke pulmonary oedema, though the fact that the blood volume is reduced in anuria makes this accident less likely. The rigor which occurs about two hours afterwards is of no significance and is not in itself a severe reaction.

Indications and Results. This is a relatively ineffective method of treatment for the volume of fluid exchanged is small in comparison with the body water. It is, however, invaluable under two conditions : at the onset of anuria if there is haemolysis, for it is the only means for withdrawing free haemoglobin, and later in the presence of anaemia, low electrolyte levels, and acidosis, for it can correct all three. It is also the only available method of treating a haemorrhagic condition.
(2) Artificial kidney.

This is an apparatus for dialysing blood against a solution across a cellophane membrane (Kolff, 1947 ; Darmady, r948 ; Alwall, 1949 ; Merrill, 1952).

Technique. Several different types exist, e.g. that of Kolff and its modification by Merrill, and the more convenient one of Alwall. The following is the usual composition of the fluid used :-

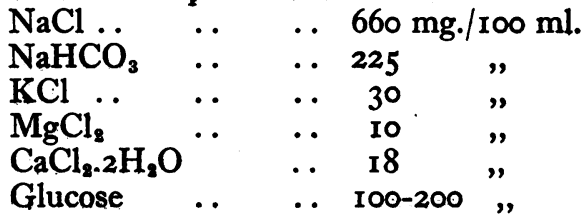

The concentration of individual constituents must be varied according to circumstances, one or more being omitted altogether if necessary. The total osmotic activity must be $395 \mathrm{~m}$.Qsm./1. Blood runs through the apparatus under arterial pressure and pour back either directly (Alwall) or forced by a special pump (Kolff, Merrill).

Complications. The chief ones are :-

r. Clotting in the apparatus (avoided by heparinization).

2. The passage of water across the membrane under the influence of the plasma proteins. This is avoided by ensuring a pressure of about $25 \mathrm{~cm}$. of water inside the circuit.

3. Progressive haemolysis in the pump. This is prevented in the newer machines.

4. Vascular collapse due to the volume of blood needed to fill the apparatus: This risk is reduced by filling it first with compatible blood.

5. Lung oedema occurring in patients overhydrated.

These risks make constant supervision essential.

Indications and results. The artificial kidney is the most efficient method of extrarenal dialysis, correcting the retention of nitrogenous endproducts, hyperkalaemia, and disturbances of electrolyte and acid-base equilibrium. It cannot correct overhydration. A urea clearance of $100 \mathrm{ml} . / \mathrm{min}$. can be attained in the largest apparatus-greater than in the patient's normal kidneys. But rapid and sensitive methods of controlling blood levels are essential, or gross disturbances may result.

(3) Peritoneal dialysis.

In this method, blood is dialysed against an artificially induced ascites, the peritoneum serving as the semi-permeable membrane.

Technique. (Tanret et al., 1952 ; Derot et al., I95I). A puncture is made in the left iliac fossa under local anaesthesia, and the dialysing fluid introduced through a plastic catheter. After introducing 2 or 3 litres in about an hour and a 
half, a tube is introduced into the right iliac fossa to siphon off the fluid. The hypertonic fluid recommended by Abbott and Shea (1946) is usually used, with the following composition : $\mathrm{NaCl}$ 6.I gm. ; $\mathrm{KCl}, 0.35$ gm. ; $\mathrm{MgCl}_{2} \cdot 6 \mathrm{H}_{2} \mathrm{O}$, 0.05 gm. ; $\mathrm{CaCl}_{2} .2 \mathrm{H}_{2} \mathrm{O}$, 0.23 gm. ; $\mathrm{NaH}_{2} \mathrm{PO}_{4}$, 0.07 gm. ; $\mathrm{NaHCO}_{3}, 2.20$ gm. ; glucose, 20 gm. ; penicillin 100,000 units, streptomycin 0.I gm., Heparin ro mg. ; sterile pyrogen-free water to I litre.

For convenience, a stock solution ten times as strong but without the bicarbonate is made up, which can be sterilized by heat, the bicarbonate being added just before use, as a sterile solution.

The composition is modified according to the effect required, but the solution is always made I5-30 m.Osmol./1. hypertonic with regard to plasma by adjusting the glucose. For hyperkalaemia, the potassium is omitted, for instance.

About 2 litres of fluid can be removed an hour. Because of the danger of infection, it has been our usual practice in the last few years to limit the duration of treatment. When stopping the dialysis, both catheters are used to drain the fluid and light pressure applied to the abdomen.

Complications. Oedema of the abdominal wall around the entering catheter usually means it has not been inserted far enough. Faulty drainage results from kinking of the catheter or faulty alignment, demanding careful adjustment. Intestinal perforation or haemorrhage are very rare. Post-operative infection is an important complication-rigid asepsis is difficult to achieve. The infection may not only be exogenous - it may arise from unsuspected appendicular or tubal infection. If great care is not taken in the control of the dialysis, overhydration and acute pulmonary oedema may occur.

Indications and results. This is an effective measure, removing perhaps 20-40 gm. urea, and applicable to hyperkalaemia and salt and water retention. But it is unpleasant, carries the risk of complications, and is not easy to repeat. It is contra-indicated in inflammatory conditions of the peritoneum or pelvis.

(4) Intestinal perfusion.

In this, the intestinal mucosa is the dialysing membrane (Hamburger et al., I95ob; Twiss, 1950).

Technique. A double-barrelled catheter is used, opaque to $\mathrm{X}$-rays, with an oiled metal stilette, about 3 metres long. One channel is used for the perfusing fluid, the other for blowing up a balloon a few $\mathrm{cm}$. from the end. (Miller-Abbott tubes can be used.) The tube is introduced through one nostril and rapidly passed down to the stomach. It is then manipulated through the pylorus into the duodenum under radioscopic control. If gastric contractions are absent, the injection of prostigmine subcutaneously or of $I$ to $2 \mathrm{gm}$. 䗆 hypertonic sodium chloride intravenously may stimulate them. Once the pylorus is passed the $\frac{a}{3}$ stilette is removed and the balloon inflated to $\$$ assist the progress of the tube. The perfusion is $\frac{2}{L}$ begun when the end is $40 \mathrm{~cm}$. beyond the pylorus. It takes I or 2 hours to get the tube into place, sometimes much longer.

The patient is placed in a special bed, with a 흠 hole in the mattress in which a funnel collects: fluid from the rectum and empties into a graduated $\vec{\square}$ receptacle. We use a bed in which the subject can be weighed. The fluid is pumped down the tube electrically, passing first through a waterbath at body temperature, at a controlled rate. The $\overrightarrow{\vec{\omega}}$ fluid used is always made hypertonic (to counter- $\stackrel{\omega}{\circ}$ act the active absorption of water and solutes) with ${ }_{\overparen{C}}$ sucrose which is only slowly absorbed. The 3 . freezing point of the fluid should be $0.05^{\circ}$ to $\omega_{0}$ $0.1^{\circ} \mathrm{C}$. below that of plasma for a flow of $3-4 \dot{\omega}$

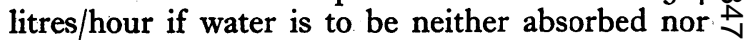
excreted. To remove an electrolyte, the fluid if must be free of that constituent ; if none is to be $\stackrel{F}{v}$ removed it should have the following composition; 은 Sucrose 86 gm. ; glucose 7.7 gm. ; $\mathrm{NaSO}_{9}^{-}-$ $2.5 \mathrm{gm}$.; $\mathrm{NaH}_{2} \mathrm{PO}_{4}, 0.05 \mathrm{gm}$. ; $\mathrm{KCl}, 0.2 \mathrm{gm}$. $\mathrm{NaHCO}_{3}$, 1.0 gm.; NaCl, 0.7 gm.; water, I litre

Procedure. Three to four litres per hour is $\frac{0}{3} \frac{\mathbb{D}}{3}$ suitable speed of flow, avoiding both water absorption and removal. 20-30 minutes after the start the rectal evacuation begins, and this ma go on for 30-60 minutes after the end. Each: perfusion lasts 2-3 hours, and the tube can be kept in place between each one. The composition of the fluid can be modified at any time according to the blood chemistry, and the same exact methods of control are necessary as with other techniques. The minimum consists in checking the weight of $\overrightarrow{\vec{P}}$ the patient, the blood pressure, the E.C.G., and, $\frac{0}{3}$ hourly, the plasma specific gravity and effective osmotic pressure: The electrolytes, especially potassium and bicarbonate, are checked before and after every perfusion. This laboratory control 3 gives the method great safety and flexibility.

Complications. Done in this way, we know of no accidents. But we may mention the possibility 8 of (a) post-nasal bleeding caused by the tube, when there is a haemorrhagic syndrome, $(b)$ the 0 development of diarrhoea after many perfusions in some subjects; the exact cause has not been established.

Indications and results. The urea clearance $\stackrel{N}{\circ}$ given by perfusion is about IO- $15 \mathrm{ml} / \mathrm{min}$. N (about the same as for peritoneal dialysis); so that when the blood urea is $300-400 \mathrm{mg}$./100 ml. it o removes 5-10 gm. urea in 2-3 hours. This is enough, if catabolism is not excessive, for a daily perfusion to prevent any further rise. The greater $\stackrel{\oplus}{+}$ 
TABLE 4

\begin{tabular}{|c|c|c|c|c|}
\hline & Major Indications & Minor Indications & No Action & Contra-indications \\
\hline $\begin{array}{l}\text { Exsanguino- } \\
\text { transfusion }\end{array}$ & $\begin{array}{l}\text { Haemolysis } \\
\text { Anaemia } \\
\text { Fixed acidosis } \\
\text { Haemorrhagic } \\
\text { syndrome }\end{array}$ & $\begin{array}{l}\text { Azotaemia } \\
\text { Hyperkalaemia }\end{array}$ & $\begin{array}{l}\text { Salt and water re- } \\
\text { tention }\end{array}$ & $\begin{array}{l}\text { Hyper-electro- } \\
\text { lytaemia } \\
\text { Increased blood } \\
\text { volume }\end{array}$ \\
\hline Artificial kidney & $\begin{array}{l}\text { Azotaemia } \\
\text { Hyperkalaemia } \\
\text { Hypernatraemia } \\
\text { Fixed acidosis }\end{array}$ & & $\begin{array}{l}\text { Water retention } \\
\text { Anaemia }\end{array}$ & $\begin{array}{l}\text { Haemorrhagic } \\
\text { syndrome } \\
\text { Circulatory } \\
\text { collapse }\end{array}$ \\
\hline $\begin{array}{l}\text { Peritoneal } \\
\text { Dialysis }\end{array}$ & $\begin{array}{l}\text { Azotaemia } \\
\text { Water retention } \\
\text { Hypernatraemia } \\
\text { Hyperkalaemia }\end{array}$ & Fixed acidosis & Anaemia & $\begin{array}{l}\text { Haemorrhagic } \\
\text { syndrome } \\
\text { Peritoneal infection } \\
\text { Pelvic infection }\end{array}$ \\
\hline Intestinal perfusion & $\begin{array}{l}\text { Azotaemia } \\
\text { Hyperkalaemia } \\
\text { Hypernatraemia } \\
\text { Water retention } \\
\end{array}$ & & $\begin{array}{l}\text { Fixed acidosis } \\
\text { Anaemia }\end{array}$ & $\begin{array}{l}\text { Diarrhoea } \\
\text { Haemorrhagic } \\
\text { syndrome }\end{array}$ \\
\hline
\end{tabular}

This work was carried out with the aid of a grant from the Caisse Nationale de Securite Sociale. (Institut National d'Hygiene, Professeur Bugnard.)

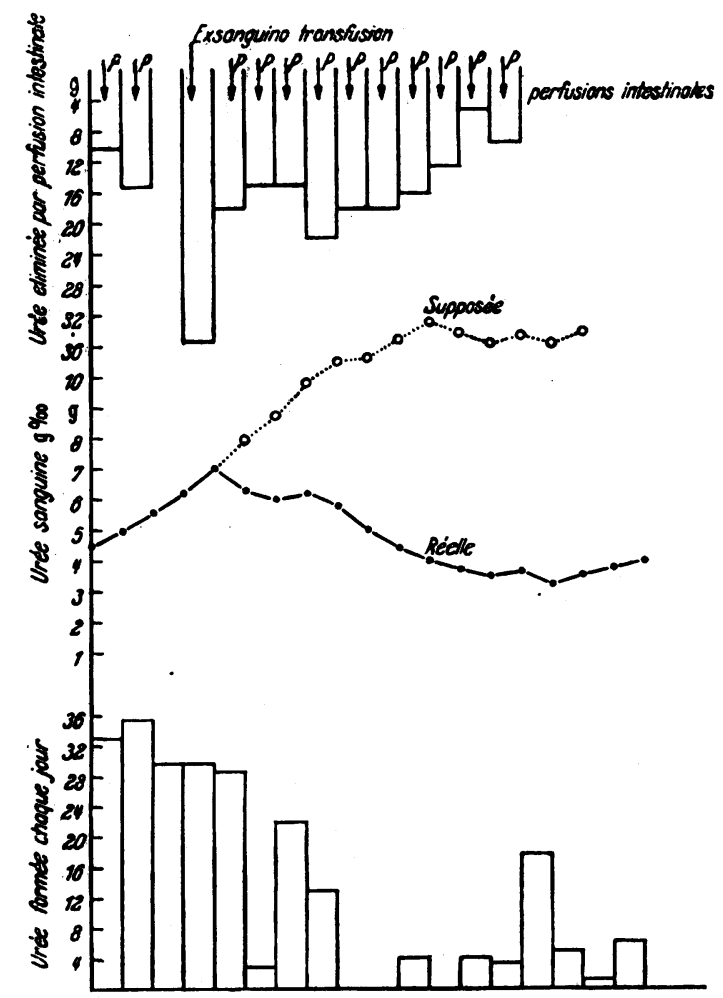

Fig. 6.-Anuria after intravascular haemolysis, treated by intestinal perfusion. From above downwards: Urea formed daily; theoretical blood urea in absence of treatment; actual blood urea; urea removed. (Hamburger et al., 1950, Sem. Hop. Paris, 26, 3901.) the blood level the greater the amount of urea removed, so that it is a good plan to defer its introduction until the level is above $300 \mathrm{mg}$./100 ml. (Fig. 6).

Intestinal perfusion can be used for the treatment of hyperkalaemia. It is very effective, the plasma potassium being reduced from dangerous levels in a few hours. Extra- or intra-cellular overhydration can also be treated by the use of strongly hypertonic solutions, with salt if water is to be removed from the extracellular compartment : without it, if extracellular dehydration is required. One to three litres may be removed in 2-3 hours. Intestinal perfusion makes it possible to correct simultaneously the retention of urea, potassium, sodium and water. There are, however, some drawbacks : its efficiency is not great and varies from one patient to another and from one perfusion to another. It is ineffective for removing sulphate and phosphate. It is, however, probably the best technique where an artificial kidney is not available.

Table 4 summarizes the principle indications and contra-indications for each of these four types of therapy.

\section{BIBLIOGRAPHY}

ABBOTT, W. E. and SHEA, P. (1946), Amer. Ұ. med. Sci., 2II, 312. ALWALL, N. (1949), Acta med. scand. Suppl., 229.

BORST, J. G. G. (1948), Lancet, i, 824.

BULL, G. M., JOEKES, A. M. and LOWE, K. G. (1950), Clin.

BuLL, G., M., JOEKES, A. M., LOWE, K. G. and EVANS, G. (I949), Lancet, ii, 229.

CASTAIGNE, P. (1949), Sem. Hop. Paris, $25,2680$.

DARMADY, E. M. (1948), Proc. R. Soc. Med., $41,418$.

DAUSSET, J. (1950), Arch. intern. Med., 85, 416 .

DEROT, M., LEGRÁIN, M., BERNIER, J. J. and PIGNARD, P. (I05I), Congr. Fr. de Med., XXVIIIme Session, Brussels. EVANS, B. M., MILNE, M. D., HUGHES JONES, N. C. and YELLOWLEES, H. (1953), Lancet, ii, 791.

Bibliography continued on page 493 


\section{Addendum}

Since completion of this paper, one of the patients (J. R.) had a recurrence of symptoms almost identical to those during her previous attack. She was seen in her home and was found to have diffuse upper abdominal tenderness with a suggestion of an elongated thickening, possibly a loop of jejunum, in the left hypochondrium. As her symptoms did not subside with full sedation she was readmitted to hospital.

Blood examinations revealed a recurrence of eosinophilia with unusually high figures of 8,000 and 10,000 per cu.mm. on successive days with a peak rise to $I I, 600$ in a total white count of 27,300 per cu.mm.

As A.C.T.H. has been advocated in allergic conditions, it was decided to give her a short course. A dramatic fall in circulating eosinophils was produced with complete remission of symptoms (Fig. II). The drug was discontinued after six days and although the eosinophil count subsequently rose, the patient remained well and was allowed to return home.

\section{BIBLIOGRAPHY}

BARRIE, H. J and ANDERSON, J. C. (1948), Lancet, 855, 1007. BERGSTRAND, H. (1946), Ұ. Path. Bact., 58, 399.

HERRARA, J. M., and DE LA GUARDIA, J. (1948), Arch. Hosp. Santo Tomas, 3 , 10

KAIJSER, R. (1937), Arch. p. Klin. Chir., 188, 36.

LOEFFLER, W. (1032), Beitr. Klin. Tuberk., 79, 368.

MOLONEY, G. E. (1949), Lancet, $1,412$.

POLAYES, S. H. and KRIEGER, J. L. (1950), Y.A.M.A., 143, 549 RUZIC, J. P., DORSEY, J. M., HUBER, H. L., and ARM. STRONG, S. H. (1952), F.A.M.A. 149, 535

SPENCER, J. R., COMFORT, M. Wै., and DAHLIN, D. C. VANEK, J. (1949), Am. F. Path., 25, 397.

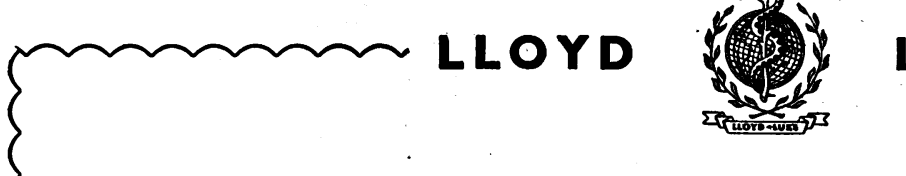

\section{LUKE}

FLOREY

LE QUESNE

W YLIE

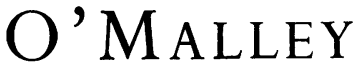

LECTURES ON GENERAL PATHOLOGY, edited by SIR Howard FloReY, M.D., F.R.C.P., F.R.S., Professor of Pathology, University of Oxford.

xiv +734 pp. 344 illustrations, 4 colour plates (1954) 63s. net

FLUID BALANCE IN SURGICAL PRACTICE, by L. P. LE QUESNE, B.M., B.Ch., F.R.C.S., Assistant Director, Department of Surgical Studies, Middlesex Hospital. viii +130 pp. 41 illustrations

(1954) 17s. 6d. net

PRACTICAL MANAGEMENT OF PAIN IN LABOUR, by W. D. WyLIE, M.B., M.R.C.P., F.F.A., Anaesthetist, St. Thomas's Hospital and the National Hospital for Nervous Diseases.

$x i i+148$ pp. 42 illustrations

(1953) 18s. 6d. net

MICHAEL SERVETUS, a translation of his geographical, medical and astrological writings, by Professor ChARLes D. O'MALLEY, Stanford University.

208 pp. 7 illustrations

(1953) 21s. net

\section{NEWMAN STREET, LONDON, W.}

Continued from page 475-Gabriel Richet, fean Crosnier and Georges Mathé

FUNCK-BRENTANO, J. L. (1953-4), 'Contribution a l'étude du mécanisme physiopathologique de l'anurie au cours de néphropathies aiguës.' Thèse, Paris.

HAMBURGER, J., CROSNIER, J. and MATHE, G. (I950), Bull. Soc. Med. Hop. Paris, 66, $170 \mathrm{x}$.

HAMBURGER, J. and MATHE, G. (1951), Pr. Med., 59, 265.

HAMBURGER, J, and MATHE, G. (I95 I), Pr. Med., 59, 265. Bull. Soc. Med. Hop. Paris, 66, 1716 .

HAMBURGER, J., MATHE, G. and CROSNIER, J. (1950b), Sem. Hop. Paris, 26, 3918 .

HAMBURGER, J. and MATHE, G. (1952), 'Métabolisme de l'eau' Paris, Flammarion.

HAMBURGER, J. and MATHE, G. (1954), 'Ciba Symposium, The Kidney.' London, Churchill.

HAMBURGER, J. and RIĆHET, G. (1952), Bull. et Mim. Soc. Med. des Hptx de Paris, 68, 368, 375.

HAMBURGER J., SERANE, J. and COURNOT, L. (195I), Sem. Hop. Paris, 27, 2289.

HARRIS, H., McDONALD, R. and WILLIAMS, W. (1952), Aust. F. exp. Biol., Med. Sci., 30, 33.
HARVEY, C., KNOWLES, J. and KAPLAN, S. A. (1953), Arch. intern. Med., 92, 189 .

KOLFF, W. J. (1947), New ways of treating uraemia. The artificial kidney, peritoneal lavages, intestinal lavage.' London, Churchill.

MERRILL, J. P. (1952) New Eng. F. Med., 246, 17

MATHE, G. and CROSNIER, J. (1950), F. Urol. med. chir., 2 II6. MUIRHEAD, E. E., JONES, F. and GROLLMAN, A. (I952) F. Lab. clin. Med. JONES,
II. 505 . RICHET, G., ALAGILLE, D. and FOURNIER, E. (1954),

TANRET, P., BERNIER, J. J., LEGRAIN, $M$, and PIGNARD, $P$. (1952), $\mathrm{La}$ dialyse péritonéale. in Traitement des néphrites aiguës anuriques.' Masson, Paris.

TWISS, E. E. (1950), 'Treatment of uremia by dialysis and other methods with special regard to the principles and scope of intestinal dialysis.' M. Wytard, Rotterdam.

VALLERY-RADOT, PASTEUR, MILLIEZ, P., LAROCHE C LHERMITTE, 'F. and LEVAVASSEUR (1948), Bull. Soc. Med. Hop. Paris, 64, 908. 